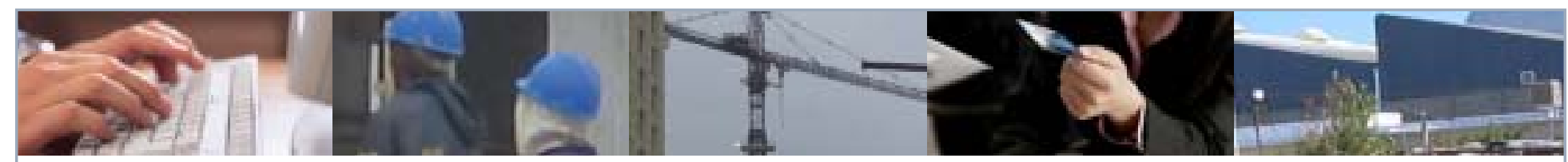

\title{
Determinants of Job Search Strategies: Evidence from the Khayelitsha/Mitchell's Plain Survey
}

\author{
Volker Schoer
}

Accelerated and Shared Growth in South Africa:

Determinants, Constraints and Opportunities

$$
18 \text { - } 20 \text { October } 2006
$$

The Birchwood Hotel and Conference Centre Johannesburg, South Africa
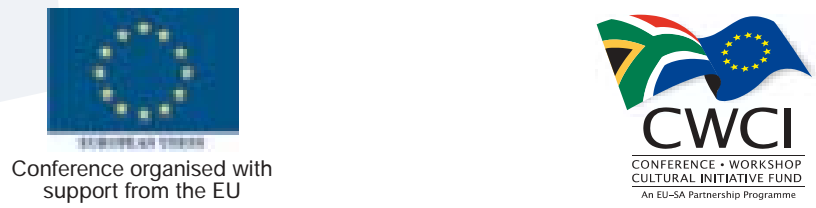


\section{Determinants of Job Search Strategies: Evidence from the Khayelitsha/ Mitchell's Plain Survey ${ }^{1}$}

\section{Abstract}

Over recent years, increasing attention has been paid to factors which determine the job search behaviour of the unemployed in South Africa. We provide a framework for analysing the choice of search strategies utilised by unemployed job searchers. Using a simple search model, we show that individual as well as household characteristics either constrain or facilitate the use of particular search methods. Our findings therefore illustrate that the jobseeker's choice of a particular search method is a compromise between what the job-seeker considers to be the most effective way to find job and what is actually a feasible method. This highlights the need to carefully reconsider the way in which we define and statistically evaluate the labour force participation of the South African unemployed.

\section{Introduction}

Since 2001 South Africa's broad unemployment rate has hovered around 41\%, while the narrow unemployment rate has been just below 30\%. In the face of mass unemployment, unemployed job-seekers constantly have to ask themselves "how do I get a job?" High unemployment rates force unemployed workers to carefully consider the advantages and disadvantages of job search itself and the search method they pursue.

There are two aims to this paper. First, we take stock of the relationship between the debate over the measurement of unemployment in South Africa and the application of the search paradigm for analysing South African unemployment. This is a fruitful dialogue. However, it needs tidying up and extension in order to allow for a more productive link with the empirical modelling of

\footnotetext{
${ }^{1}$ Volker Schoer would like to thank the Centre for Social Science Research (CSSR) and the Southern African Labour and Development Research Unit (SALDRU) at the University of Cape Town for the intellectual and financial support.
} 
unemployment in South Africa. Thus far, there is a paucity of empirical work on the kinds of search strategies that are used by the unemployed and the reasons why they use these strategies rather than others. We use and extend the South African literature to present a search model that explains the various factors influencing the decision of the unemployed to look for a job with a particular search method. This allows us to proceed to our second aim in the paper; namely to use a unique 2000 labour market survey in the Western Cape to investigate factors which determine the search behaviour of unemployed residents in the Mitchell's Plain magisterial district.

The Khayelitsha/Mitchell's Plain Survey (2000) shows that close to two thirds of the currently employed in this area found their jobs through social networks. Thus, they found employment because friends or relatives told them about a job or even organised a job for them at the contact's workplace. The remaining one third got employed through more formal channels like newspaper advertisements or through other active methods such as contacting employers directly. The unemployed job-seekers in Khayelitsha and Mitchell's Plain exhibited search behaviour which seemed to be consistent with the way in which the currently employed found employment. Slightly more than one third of the job-seekers used only active search methods to look for a job, while the remaining job searchers either relied exclusively on social networks to find a job or pursued a mixed search strategy of active methods and social networks.

It is important to try and understand which factors determine the choice of the search method of the unemployed. Is it solely influenced by the search method's success rate in getting people employed or is the choice of the search method determined by other factors? It is argued in this paper that the unemployed pursue search methods that are a compromise between what they perceive to be an effective way for them to search for a job and what is feasible for them. Individual, household and neighbourhood characteristics as well as labour market conditions either facilitate or constrain the pursuit of certain search methods.

\section{Unemployment and Job Search in South Africa}

There has been an extensive debate in South Africa about which definition of the unemployment rate most appropriately represents the nature of unemployment in South Africa (Kingdon and Knight 2000, Dinkelman and Pirouz 2001, Nattrass 2002). The main disagreement among scholars revolves around the criteria that define if a jobless person actually participates in the labour market. 


\subsection{The Definition of Unemployment}

To investigate the level of labour participation and to calculate the unemployment rate, surveys are conventionally based on the 'activity principle' meaning "a person's labour market status is determined by what he or she was actually doing during a specified (short) period prior to the survey interview" (Nattrass, 2002: 3). Based on their activity, people are then categorised as employed, unemployed or non-participating.

Following the standard International Labour Organization (ILO) definition, 'unemployment' refers to people who are not working for some kind of financial compensation but are: a) willing to work; b) available for work; and c) actively searching for work (Statistics SA, 2002).

The fulfilment of conditions $a, b$ and c defines a 'narrow' or 'strict' definition of unemployment where the jobless person not only has to be willing and available for work but must also have been actively searching for a job in a given time period. $^{2}$ A 'broad' or 'expanded' definition of unemployment requires the fulfilment of conditions a and b, but does not require condition c. Hence, to be categorised as broadly unemployed a jobless person only has to be willing and available for work without having done any active search for a job in the reference period prior to the survey.

Clearly, the coherence and usefulness of this typology hinges on the derivation of an acceptable definition of "actively searching" under c. As will become evident in the review of the search literature, this is particularly difficult in the South African context and is the source of most of the contention regarding measured unemployment in South Africa. Thus, it is the definition of active job search that sits centre-stage in dividing jobless people into either the narrowly defined unemployed who through active search indicate their willingness to participate in the labour market and/or non-participants who might want work but seem to do nothing "active" to find a job. Participation of the unemployed in the labour market is therefore simply based on the dichotomy between active searching and non-searching.

Unfortunately for South Africa, it seems that more people have become discouraged over the last couple of years with the strict unemployment rate falling from around $30 \%$ in 2000 to only $26 \%$ in 2004 while the broad unemployment rate remained at $41 \%$. In addition, approximately $62 \%$ of the non-searching, are females and over $90 \%$ are African. Only one third of them are older than 35 years of age and although the majority of the non-searching have poor educational background, only $7 \%$ had no education while more than

\footnotetext{
${ }^{2}$ Normally, this time period is between 1 to 4 weeks prior to the survey.
} 
$60 \%$ had more than primary education. Finally, the majority of the nonsearching unemployed live in rural households. (DPRU, 2004).

These are the most vulnerable groups in South Africa which makes it imperative to understand what informs their failure to engage in search activities as defined by Statistics South Africa as well as to detail any search activities that they do engage in but which fall outside the ambit of the official definition of active search.

\subsection{Search Behaviour in South Africa}

Following a distinction to be found in labour economics, Kingdon \& Knight (2001) suggest two explanations to account for the existence of non-searching jobless people who claim that they want a job. Firstly, a jobless person might have developed a "taste for unemployment" when there is "the possibility of redistribution within the household, [i.e.], higher household income may lower search effort among its unemployed members. If high-income households support their poorer members according to need, there can be an incentive to remain needy and a disincentive to do job-search"(Kingdon and Knight, 2001: 7). Contrary to this explanation, the 'discouraged-worker' hypothesis argues that non-search is the outcome of the perception of the jobless person that the probability of finding a job is too low relative to the cost of search. Thus, because the jobless person finds him- or herself in adverse economic conditions placing a high cost on search, the "decision not to search is a choice made under duress"(Ibid: 8).

This is a particularly clever line of argument as it challenges the clear mapping between the narrow and broad definitions of unemployment and those who want to search and those who do not. If the major reason for lack of search is the lack of resources to search, then excluding such non-searchers from the definition of unemployment and from the ambit of policy attention is clearly unacceptable.

Kingdon and Knight (2000) investigated whether the non-searching unemployed are a distinctly different group from the searching unemployed. Their findings suggest that these two groups are not really distinguishable by individual characteristics. Rather, non-search is the outcome of discouragement as "jobsearch is hampered by impediments such as poverty, cost of search, long duration of unemployment, and adverse local economic conditions" (ibid: 1-2).

Following the search-constraints argument, various studies in South Africa (Wittenberg, 1999; Wittenberg 2001; Dinkelman and Pirouz, 2001; Dinkelman, 2004; Nattrass, 2002; Kingdon and Knight, 2000; Kingdon and Knight 2001) have started to shed light on the search behaviour of the unemployed and have 
thereby contributed greatly to the unemployment definition debate. These studies have been guided by the two ideas. First, no matter how motivated the individual, job search is not frictionless and costless and therefore requires resources. Lack of search may not signal a lack of desire to be employed. Second, search is about information which can be gathered through labour market signals but also through many non-market interactions involving individuals, households, communities and firms. (Wittenberg, 2001). This complexity is not adequately captured by the current definition of active job search. In empirical work, these two considerations have driven researchers to give attention to the probability of finding a job and the cost of search relative to the expected benefits of the search activity. Following this line of argument, Dinkelman and Pirouz (2001) argue that :

\begin{abstract}
"The net benefits of search are likely to be low when individuals are not able to access the correct type or quality of labour market information to ensure successful search. Information barriers in the labour market are generated through the individual characteristics of an unemployed person, as well as household and community or regional characteristics. For example: in South Africa, the costs of search facing a second-language English speaker living in rural Kwazulu-Natal in a household with no access to a telephone or regular newspapers, and with no other employed relatives are presumably very high. Add to this the reduced probability of this individual finding a job without matric or tertiary qualification and with no prior work experience, then the choice of non-search or the onset of discouragement may indeed be rational"(ibid:8).
\end{abstract}

Having raised these questions, more recent papers have increasingly concentrated on the impact of different household characteristics on the search activity of the unemployed. Papers by Wittenberg (2001) and Dinkelman (2004) investigate how household and neighbourhood characteristics affect search behaviour. Wittenberg argues that the search activity is strongly influenced by the structure of the household. It "impacts on all the variables involved in the decision: the value of finding a job, the cost of searching as well as the value of non-market activities"(Wittenberg, 2001: 5). Besides individual characteristics Dinkelman (2004) identifies four possible ways in which the household impacts on job search. Households function as private security nets, productive units, information networks, and as creators of a work and/or search culture.

Given the importance of job-seeker's social structure, Seekings (2003) argues that the variance in access to human and social capital leads to the creation of an 'underclass'. Especially the lack of access to employment networks creates a systematic disadvantage for the underclass' search activity in a labour market where the majority of jobs are secured through friends and family members. 
Duff and Fryer (2004) present a preliminary analysis of job search activities in Duncan village, a pre-urban township close to East London. Their study is the first to examine the factors that determine the job-seeker's choice of search methods in South Africa. For them "job search is the external labour market, in the sense that it defines the way in which employees and employers locate each other, and, as such, it is one of the most important factors determining the information structure of the labour market"(ibid: 2).

They distinguish between three forms of search: formal search (newspapers and/or employment agencies); word-of-mouth (assistance from relatives and friends, i.e. social networks); and place-to-place (direct contact of job searchers by going to factories and/or knocking on doors). The search categories are categorised according to the type of information transmitted. Formal search is possible if all relevant information about the job and the job-seeker can be transmitted through "impersonal, strictly market channels of applications and agencies"(Ibid: 5). When job-seekers are "unable to provide employers with a credible signal of their quality"(Ibid: 6), they have to rely on social networks to get access to the labour market with the help of referrals from friends and relatives. Wittenberg (1999) suggests a similar rationale for using social networks when seen from the employer's position. If matric qualifications are "highly variable between individuals" which has reduced the signaling function of educational attainment and "in a situation in which large numbers of the unemployed all posses the matric, its utility as a potential sorting device for an employer is reduced"(Wittenberg, 1999: 32). The outcome is that education matters little in the employment process and employers therefore increasingly rely on informal networks to source workers. Finally, according to Duff and Fryer (2004), job-seekers will have to use place-to-pace search when they have no access to formal search or social networks.

Place-to-place is the most used search method while word-of-mouth is the least used method, but the most successful, as most currently employed found their jobs through social networks. For them, this suggests "that [networks and formal search] give better access to the labour market" (ibid: 11). Their findings support their argument. Network searchers are least educated with slightly less years of education than the place-to-place searchers while formal searchers are the most educated. Nevertheless, the probability of finding employment is the highest for network searchers and the lowest for place-to-place searchers. Networks and formal search methods are used by more or less the same amount of unemployed men and women while more men travel from place to place. Finally, on average, network searchers have been searching for the least time of all unemployed. 
The authors are surprised that despite the obvious success rate of social networks, the search method itself is under utilised by both men and women. They conclude that people do not choose different search methods. "If a searcher can generate a signal which employers trust using formal methods, that searcher will do so. If they cannot generate signals they use social networks, which are by nature exclusive, but are also by nature likely to provide a very limited set of information about jobs"(Ibid: 16).

Clearly it is important to further investigate how search is determined by the conditions the South African job-seekers face which either constrain or facilitate access to information in the labour market. The job-seeker has to gather information about vacancies and be able to signal his or her qualifications to the employer. Both these problems can be solved with various search methods which yield different success rates in fulfilling these functions. The cost of pursuing the search method in terms of financial costs and other opportunities forgone further constrain the ability of the searcher to actively search. The literature reviewed above suggests that in these circumstances the use of informal information networks rather than active search methods can be a rational decision of the jobless person. Having contacts with employed friends and relatives significantly increases the probability of finding a job while it reduces the cost of search.

Yet, having shown the importance of these possibilities, there is very little detailed work on the ways in which the unemployed actually look for a job and which factors influenced their choices. Duff and Fryer's study (2004) is so far the only explanation for the pursuit of different search methods in South Africa. The purpose of this paper is to shed some light on the factors which influence the choice of the search method and thereby tries to improve the understanding of the search process itself. The focus is on factors that determine the choice of the search method.

We proceed as follows. To identify possible factors that determine the choice of the search method we have to establish a theoretical framework which explains the decision to search and the choice of the search method. Second, we use the 2000 Khayelitsha/Mitchell's Plain (KMP) survey to analyse factors which characterise groups who use different search methods. In this respect, the design of the KMP survey proves very useful. Employed workers were asked how they got their current job, and unemployed workers were asked to report all search methods they use to look for a job. While Nattrass (2002) shows that the design of the skip patterns in the national labour force surveys is likely to prevent a proper understanding of the search behaviour of the unemployed and in particular their use of networks, this is not true of the KMP. Thus, the instrument is well suited to the task. 


\title{
3. Job Search: A Theoretical Framework
}

The unemployed individual has to decide how to organise his or her search activity to yield the best results in terms of finding employment. Various factors which either constrain or facilitate the job-seeker's search activity force the jobseeker to choose a search strategy which enables him or her to participate in the labour market.

Like most markets, the labour market is characterised by imperfect information which requires that the market participants engage in the gathering and acquisition of relevant market information in order to make informed decisions. According to Pissaridis (2000):

\begin{abstract}
"Trade in the labour market is a nontrivial economic activity because of the existence of heterogeneities, frictions, and information imperfections. If all workers were identical to each other and if all jobs were also identical to each other, and if there was perfect information about their location, trade would be trivial. But without homogeneity on either side of the market and with costly acquisition of information, firms and workers find it necessary to spend resources to find productive job matches. The heterogeneities may be in the skills possessed by workers, on the one hand, and those required by firms, on the other. They may be in the information possessed about the job. Or, they may be in the location of jobs, and workers and in the timing of job creation in different locations. In this environment there is uncertainty about the arrival of good jobs to job-seekers and good workers to hiring firms..." (ibid: 3-4).
\end{abstract}

Due to existence of market frictions, it can be assumed that higher search effort potentially increases the probability of finding a job while at the same time, more search effort leads to higher search costs. In the end, "a worker will search for wage offers until the expected marginal return equals the marginal cost of search" (Stigler, 1962: 96).

In common with Wittenberg (1999) and Dinkelman and Pirouz (2001), we specify the expected value of search unemployment as:

$\mathrm{U}_{\mathrm{s}} \quad=\quad$ expected value of search unemployment

$=\mathrm{P}_{\mathrm{i}}^{*}\left(\mathrm{E}\left[\mathrm{w}_{\mathrm{i}}\right]\right)+\mathrm{U}_{\mathrm{i}}-\mathrm{C}(\mathrm{s})$

where $P_{i}$ refers to the individual's probability of finding a job multiplied by the expected wage $\mathrm{E}\left[\mathrm{w}_{\mathrm{i}}\right]$, while $\mathrm{U}_{\mathrm{i}}$ refers to the individual's value of unemployment and $\mathrm{C}(\mathrm{s})$ to the costs of search. What the equation clearly shows is that the jobless person has an incentive to start searching when $\mathrm{P}_{\mathrm{i}}^{*}\left(\mathrm{E}\left[\mathrm{w}_{\mathrm{i}}\right]\right)>\mathrm{C}(\mathrm{s})$.

The question each job-seeker has to ask himself is which search method gives a high probability of finding a job without costing too much. The decision to search and the choice of the search method are simultaneous processes which 
are interlinked. If search is simply the sum of all search methods pursued then the unemployed is constantly in the process of deciding to search by evaluating the expected net benefits of the various search methods. The search benefit is determined by the ability of the various search methods to generate net benefits with respect to the probability of finding a job and the search cost they create. At the same time, the job-seeker has to consider the extent to which these methods are available and feasible. Based on the evaluation of the search methods, the job-seeker will then decide to pursue them and engage in search or not to search at all. Thus, we claim that in order to understand job search one has to understand the various factors which determine the choice of the search method. Because these factors which influence the benefits of the search methods can change over time, the unemployed job-seeker will constantly have to reassess the benefit of search.

Figure 1 shows a schematic representation of the various factors influencing the continuous decision-making process of the unemployed to start searching and the choice of the search method.

\section{Figure 1: Factors influencing the Decision to Search and the Search Method}

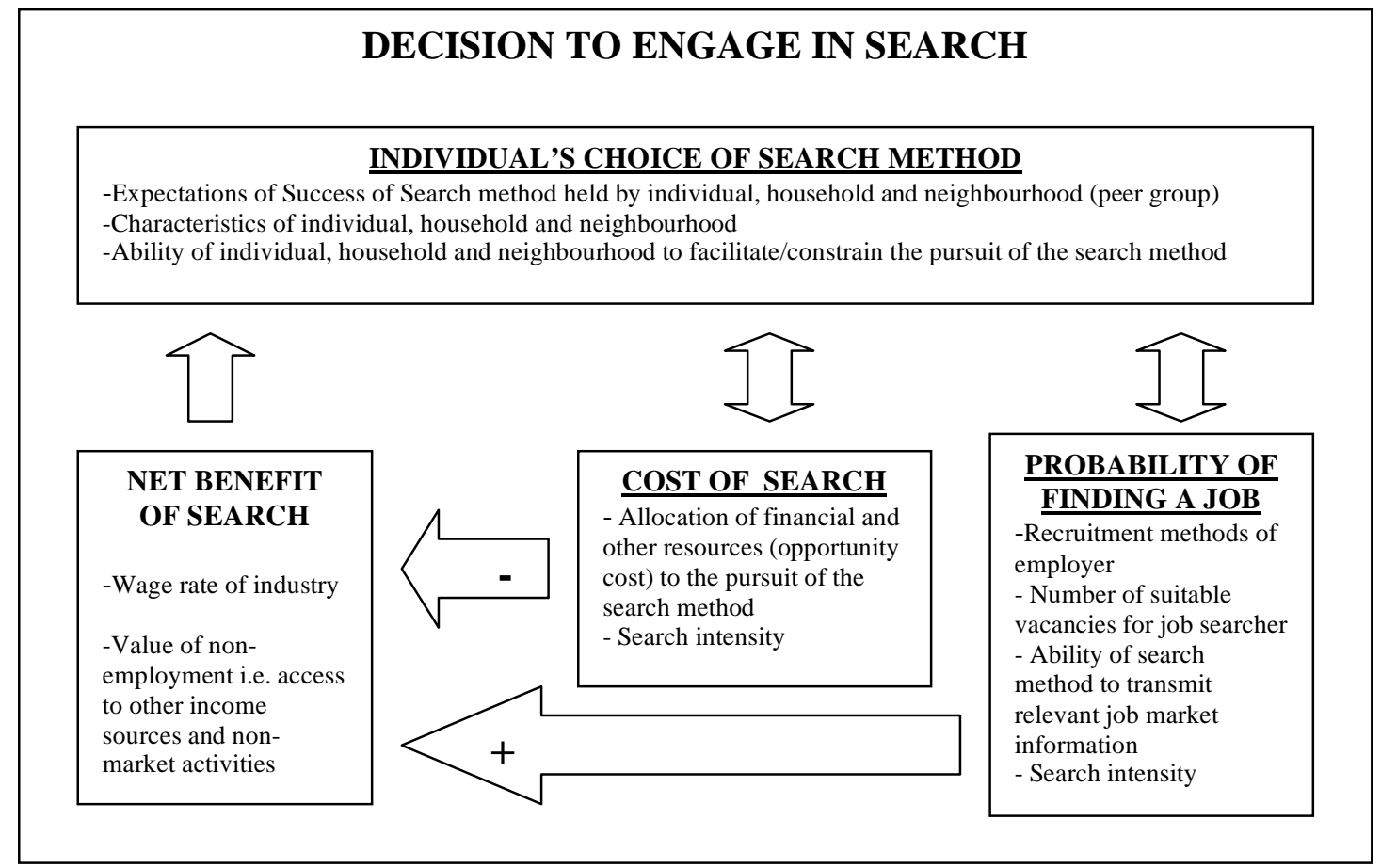

Figure 1 illustrates the various steps which the unemployed has to consider if he wants to engage in job search. The sub-points in each box indicate possible factors influencing the decision making process. 
As the unemployed decides to look for jobs, they have to choose which search methods yield the best results. The job-seeker has to consider the cost of pursuing the search method and the success of finding a job. This decision of the individual is not made in a social vacuum. The perception of the success of the search method is informed by previous experiences of the job searcher as well as reported experiences from other household members and peer groups. At the same time it might be the household or the peer group which facilitate the pursuit of the search method. Following the social capital argument, being socially embedded can create an advantage for the job-seeker through for example giving access to financial resources to cover the search cost or by acting as information transmitters. But, while social embeddeness might facilitate some search methods, it can also act as an obstacle to the pursuit of other search methods. Norms and customs in the household and the community determine the social position and the role of the individual and might therefore dictate the option of activities which are available to the individual. This might act as a constraint to the pursuit of certain search methods and in the worst case scenario, this may deny the individual any opportunities to search for a job. Under these types of social obligations falls the commonly held expectation that females, especially when married, should take care of the household, children and the elderly. When other household members expect the female to perform such duties, it might be impossible for her to leave the house in order to search for a job.

The cost of search reflects the amount of resources allocated to the pursuit of the search method. Dependent on the nature of the search method, the more intensively the method is pursued, the more resources have to be allocated to the search activity. Thus, financial as well as time constraints can make some search methods unfeasible. As explained above, household characteristics can either facilitate or further constrain the pursuit of such methods.

With respect to the probability of finding a job, the search intensity alone does not determine search success. The transition from unemployment into employment is the outcome of a two stage process. The unemployed job-seeker first has to locate a firm with a vacant position and only then can he try to get the job. Thus, the probability of finding a job should be divided into the job searcher's probability of locating a job and the probability of getting the job. Each probability is affected by different factors, so that the probability of finding a job is dependent on a range of individual, household and local labour market characteristics which make the search method 'effective' in the eyes of the searcher.

Labour market conditions as well as the recruitment methods of the employer influence the ability of the searcher not only to locate a vacancy but also to 
eventually get the job. A highly skilled IT specialist will not wait on the side of the road to be picked up for a computer programmer job. No matter how much time he or she spends pursuing this search method, the expectation of success is very small. Similarly an unskilled worker will most probably have a lower success rate finding a job through the internet than by walking from factory to factory and directly asking for a job.

Clearly the probability of locating a job is strongly dependent on the recruitment process of the employer. If computer programmers were to be picked up on a daily basis on the side of the road, this search method would be highly successful compared to others. Also, if more companies were to advertise more jobs for unskilled workers on the internet, utilising the internet as a search method would be very effective for the unemployed unskilled worker.

Hence, 'locating a job' is very much the outcome of the labour market's modus operandi of how information about vacancies and available workers are communicated. Recruitment methods of the employer are dependent on cost benefit calculations. Generally, the literature on recruitment methods suggests that "firms invest more search effort in filling positions that require more education and training" (Osberg, 1993: 351). Companies have an incentive to increase search costs the higher the productivity of the desired worker and the lower the number of workers with the desired characteristic. Similar to the search of the job-seeker, companies will search until the expected marginal return equals the marginal cost of search. Recruitment of skilled workers therefore is mostly done through formal channels while unskilled workers are hired through informal channels with the main search cost imposed on the jobseeker (Stigler, 1962). When information is not available through formal channels, unskilled workers have to rely on informal channels or have to directly contact the employer.

Once the potential employee knows about a job, the probability of getting a job is dependent on the ability of the job-seeker to communicate reliable signals about his ability to the employer. When a paper qualification is a sufficient signal, formal methods can transmit the information. Formal channels will be inappropriate when a paper qualification is not sufficient because of high variability of the signal. This confirms Duff and Fryer's argument that jobseekers use the search method which allows them to send a reliable signal. At the same time, formal channels can also fail when the job requires particular personality characteristics which formal channels cannot communicate. "While the formal market is quite good at signaling worker skills - education, worker training programmes, and skill certifications - the formal job market is a very poor provider of other information desired by employers, such as worker reliability, willingness to follow direction, attitude, and 
trustworthiness"(McEntarfer, 2003: 51). In this case informal channels, i.e. social networks, can give the job-seeker an advantage. Various studies (e.g. Wittenberg 2001) have shown that having an employed household member increases the probability of employment success. One explanation for this has been the ability of the employed household member to give the unemployed household member access to relevant labour market information which effectively increases the attachment of the unemployed to the labour market, not only through the probability of getting a job but also through the probability of locating a job.

The problem is that some methods which increase the probability of locating a job and the probability of getting a job are not available or feasible for some jobseekers. If the job-seeker does not have an employed household member or employed peers, using social networks as a search method seems highly ineffective. In addition to such household characteristics, individual characteristics like health problems or physical impediments can hinder the active pursuit of more 'appropriate' methods. Lack of formal education, especially the inability to read and write, reduces the ability of the searcher to gather printed information and to respond in writing.

Finally, the net benefit of job search depends on the cost of search and the expected wage. Once there is an expected net benefit in engaging in search, there is an incentive for the unemployed to search. This then feeds back into the decision to search.

\section{Empirical Analysis of Search Activities in the Khayelitsha/Mitchell's Plain Survey}

In 2000 the Southern Africa Labour and Development Research Unit (SALDRU) in collaboration with the Institute for Social Research (ISR) of the University of Michigan developed and conducted a survey in the magisterial district of Mitchell's Plain. This area houses almost three quarters of the African and over one fifth of the Coloured Cape Town metropolitan population.

The aim of the survey was to establish a better picture of labour market issues by exploring "the extent to which livelihoods, and in particular labour market behaviour, involved individuals in multiple activities [because] high poverty and unemployment rates in South Africa necessitate that households involve their members in multiple activities as part of their livelihood strategies"(SALDRU, 2003: 2). 
Although the survey is neither representative of the Cape Town metropolitan area nor of South Africa as a whole (it only looks at an urban sample of the African and Coloured working class), it can give valuable insights into factors which influence the search behaviour of the semi- and unskilled unemployed.

\subsection{Descriptive Analysis of Job Search Methods used by the Unemployed in Khayelitsha/Mitchell's Plain}

In total, 2644 adults in 1176 households responded to questions about their individual characteristics and their labour market activities. In the "Unemployment" section of the survey, respondents had to pass certain selective questions to establish that they were currently not engaged in some kind of economic activity, willing to work and that they were available for work at conventional working hours ${ }^{3}$. These unemployed were then asked about the activities they pursue in order to find a job. The following options were read out to the respondents:

"When did you last do any of the following activities?"

1) Looked in newspapers

2) Relied on household members to tell you about a job

3) Relied on friends/family members in different households to tell you about a job

4) Relied on household members to get you a job at their workplace

5) Relied on friends/family members in different households to get you a job at their workplace

6) Went to factories and waited outside

7) Knocked on factory gates and/or visited private homes and shops

8) Visited employment agencies

9) Phoned up (or visited) old employers and asked for jobs

10) Waited on the side of the road

11) Looked on notice boards in community centres, shopping centres, shops, etc.

For the purposes of this paper, the search methods of the last week prior to the interview were analysed. Because respondents were allowed to give multiple

\footnotetext{
${ }^{3}$ The enumerator was instructed to "skip the rest of [of the Unemployment] module" when respondents positively indicated that they either were "currently working for a wage" or were "currently self-employed" and/or answered with "no' to the question "Do you want a job?" Furthermore, they had to specify if they were available during conventional working hours "Monday to Friday during the day". Every respondent used in the sample for this paper had to fulfil these conditions to be considered a 'participating' unemployed person. It is assumed that housewives, who even if they indicated that they wanted a job and were not currently engaged in some kind of financially rewarded economic activity, would specify that they were not available during conventional working hours. This assumption is necessary to allow the following interpretation of the search activities of the unemployed.
} 
responses, it was not feasible to investigate the characteristics for each search method. Following the discussion in the theoretical part of this paper, options 1, $6,7,8,9,10$, and 11 are considered 'active' search methods where the jobseeker takes some kind of initiative to pursue the method. This initiative involves spending time or other resources on the pursuit of the method. These methods are therefore defined as "active search strategies". Options 2, 3, 4, and 5 are considered 'passive' search methods as their pursuit does not involve any direct financial or opportunity costs ${ }^{4}$. These methods are therefore defined as "passive search strategies".

In this paper we consider 4 different types of search strategies: exclusive active searchers, exclusive passive searchers, mixed strategy searchers and nonsearchers. Exclusive active searchers have indicated that they have done at least one if not a combination of search options out of the active search methods $(1,6$, $7,8,9,10$, and/or 11 of the above list) but have not relied at all on household members or friends and family in different households to tell them about a job or even get them a job. Exclusive passive searchers on the other hand have indicated that they only relied on social networks, i.e. family and friends (options 2, 3, 4, and 5 of the above list) but have not engaged in any of the active search methods. Mixed strategy searchers claimed that they have used options from the entire range of search methods, i.e. that they have used at least one if not a combination of search methods from the active as well as from the passive search method options. Finally, respondents who indicated that they had done none of the given search methods during the last week prior to the survey are defined as non-searchers.

These categories follow directly the classifications created by Nattrass (2002). Her search classifications were created in response to the standard international labour force approach allowing for a far more nuanced investigation to the search behaviour of the unemployed which was one of the main objectives of the KMP survey. "The KMP data set allows us to create three new definitions of unemployment: (1) the active-searching unemployed; (2) the network-searching unemployed; and (3) the marginalised unemployed"(Nattrass \& Walker, 2005: 500). For the purpose of our paper, we decided to sub-divide the activesearching groups into exclusive active searchers and searchers who use active as well as passive channels, i.e. mixed strategy searchers. This allows us to investigate more precisely the factors which influence the choice of the job

\footnotetext{
${ }^{4}$ The decision to classify the different search methods along the dichotomy "active" and "passive" is in order to highlight the 'grey zone' of search activities. Pursuing 'passive' search, i.e. "relying on friends and family", might involve a whole range of 'activities' like keeping regular contact with your friends and family, reminding them to "keep their eyes open for you', etc. The point is that this kind of search might be perceived as "passive" as the searcher does not search first hand for the information him/herself.
} 
searcher to employ either active search methods or passive search methods. Unfortunately, because of the possibility of multiple answers, it is impractical to make an even more disaggregated breakdown of the search methods.

Figure 2 shows that more than one third of the unemployed are not searching. Of all the unemployed, $24 \%$ use exclusively active search methods, $15 \%$ rely exclusively on the assistance of friends and relatives while the remaining $27 \%$ use a mixed strategy of active and passive search channels.

\section{Figure 2: Breakdown of Search Strategies}

\section{Search Strategies of Currently Unemployed in KMP Survey}

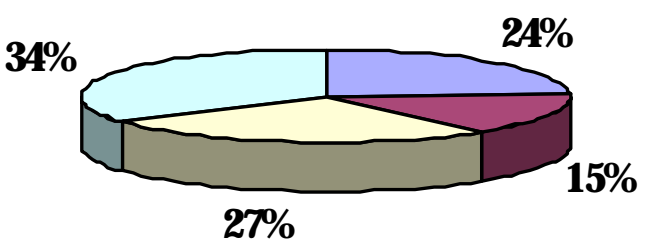

\begin{tabular}{|l|}
$\square$ Exclusive Active \\
$\square$ Exclusive Passive \\
$\square$ Mixed Strategy \\
$\square$ Non Searching \\
\hline
\end{tabular}

Source: KMP 2000, own calculations see Appendix Table A1.

Table 1 shows a breakdown of the individual characteristics of the unemployed in the various search strategies. The total racial breakdown mirrors the demographic characteristic of the Mitchell's Plain magistrate. Proportionally, the same amount of African unemployed and Coloured unemployed are either non-searching or exclusively active searchers. More Coloured searchers rely on passive search while more African unemployed pursue a mixed strategy of active and passive search.

In terms of gender differences, in the entire sample there are almost twice as many females as males. Females are proportionally more represented in the nonsearching group compared to males with a ratio of 3:1. Active and mixed strategies are more important for males while females rely more on social networks to find a job. Thus, gender seems to strongly determine the intensity of search with females having to rely on passive search or do not search at all. 
The unemployed are on average around 30 years and older. Non-searchers are the oldest group which might indicate discouragement while the searching unemployed do not show any particular age differences.

None of the unemployed groups exhibit very high levels of education with the average years of education being 8.4 years. The non-searching unemployed show the lowest level of education followed by the passive searchers. The mixed strategy searcher received the highest level of education. These results can be misleading because of the aggregation of the search methods. Following Duff and Fryer (2004), one could expect that newspaper advertisement searchers and unemployed workers registered with an employment agency might have more years of education.

Table 1. Individual Characteristics of Currently Unemployed

\begin{tabular}{|c|c|c|c|c|c|c|c|c|c|}
\hline \multirow[t]{2}{*}{$\begin{array}{l}\text { Search } \\
\text { method }\end{array}$} & \multicolumn{2}{|c|}{ Race } & \multicolumn{2}{|c|}{ Gender } & \multicolumn{2}{|c|}{ Age } & \multicolumn{2}{|c|}{$\begin{array}{c}\text { Education } \\
\text { (Years) }\end{array}$} & \multirow[t]{2}{*}{ Total } \\
\hline & Afr & Col & $\mathbf{M}$ & $\mathbf{F}$ & Med & Mean & Med & Mean & \\
\hline Excl. active & $\begin{array}{l}\mathbf{1 8 5} \\
(24 ; \\
79)\end{array}$ & $\begin{array}{l}\mathbf{5 0} \\
(25 ; \\
21)\end{array}$ & $\begin{array}{l}\mathbf{1 0 0} \\
(29 ; \\
43)\end{array}$ & $\begin{array}{l}\mathbf{1 3 5} \\
(21 ; \\
57)\end{array}$ & 27 & 31 & 9 & 8.6 & 235 \\
\hline Excl passive & $\begin{array}{l}\mathbf{1 0 9} \\
(14 ; \\
76)\end{array}$ & $\begin{array}{c}\mathbf{3 4} \\
(17 ; \\
24)\end{array}$ & $\begin{array}{c}\mathbf{4 7} \\
(13 ; \\
33)\end{array}$ & $\begin{array}{c}96 \\
(15 ; \\
67)\end{array}$ & 28 & 30 & 9 & 8.3 & 143 \\
\hline $\begin{array}{l}\text { Mix } \\
\text { Strategy }\end{array}$ & $\begin{array}{l}214 \\
(28 ; \\
82)\end{array}$ & $\begin{array}{c}\mathbf{4 6} \\
(23 ; \\
18)\end{array}$ & $\begin{array}{l}118 \\
(34 ; \\
45)\end{array}$ & $\begin{array}{l}142 \\
(23 ; \\
55)\end{array}$ & 27 & 30 & 9 & 8.9 & 260 \\
\hline Non search & $\begin{array}{l}\mathbf{2 6 4} \\
(34 ; \\
79)\end{array}$ & $\begin{array}{c}\mathbf{6 6} \\
(34 ; \\
21)\end{array}$ & $\begin{array}{l}\mathbf{8 5} \\
(24 ; \\
25)\end{array}$ & $\begin{array}{l}249 \\
(40 ; \\
75)\end{array}$ & 29.5 & 33 & 8 & 7.9 & 334 \\
\hline Total/Avg & $\begin{array}{c}771 \\
(100 ; \\
80)\end{array}$ & $\begin{array}{c}\mathbf{1 9 6} \\
(100 ; \\
20)\end{array}$ & $\begin{array}{c}\mathbf{3 5 0} \\
(100 ; \\
36)\end{array}$ & $\begin{array}{c}\mathbf{6 2 2} \\
(100 ; \\
64)\end{array}$ & 28 & 31.4 & 9 & 8.4 & 972 \\
\hline
\end{tabular}

Source: KMP 2000, own calculations, Number (Column \%; Row \%)

In the theoretical framework, we argued that household characteristics have a crucial impact on the choice of the search method as they either constrain or facilitate search. Table 2 exhibits various household characteristics which can influence the search behaviour of the unemployed.

Exclusive passive searchers constitute the only group which has a positive household employment ratio. More passive searchers live in households where at least one other household member is employed than in households with no employment. As mentioned above, this could either mean that passive searchers are living off other employed members of the household or that the employed 
member increases the probability of locating and getting a job with very low search costs. What is surprising is that of all the different search groups, mixed strategy searchers have the lowest household employment ratio. This might indicate that they have to rely more on the assistance of friends and family in other households.

This seems to be confirmed when one looks at the number of unemployed who claim that they have contacts that can get them access to the labour market. Non searchers have the lowest number of contacts in the labour market, followed by the exclusive active searchers. Exclusive passive searchers as well as mixed strategy searchers have a positive ratio of labour market contacts with exclusive passive searchers being the most connected group of the unemployed. This suggests that the choice of the search method is strongly influenced by the number of labour market contacts. The more contacts are available the lower is the incentive to search actively. The lower the number of contacts available to the unemployed, the more likely it is that the job searcher starts to engage in active search until the searcher either relies exclusively on active search or stops searching.

On average, household per capita income is lowest for mixed strategy searchers while exclusive active searchers have a slightly higher average. Non searchers and exclusive passive searchers live in households with significantly higher per capita household incomes, of which the exclusive passive searchers have got the highest. Although this could be the outcome of outliers in the data, the higher median indicates that the majority of the households do show higher incomes per person. This might indicate that non-searchers are voluntarily unemployed and exclusive passive searchers have little incentive to search more intensively.

On average, exclusive passive searchers live in households with more adult members. Exclusive active and mixed strategy searcher households have only slightly less adult members in the household while non-searchers live in households with the lowest number of adults. In terms of children, mixed strategy searchers have the lowest number of children in the household and non searchers have the highest number of children. Non searchers therefore might be constrained in pursuing active search because of being tied up in domestic duties while they lack the labour market contacts to rely on social networks.

Having established the individual and household characteristics of the various unemployment groups, we turn to the question of which search method is perceived to be the most appropriate. 
Table 2. Household and Labour Market Characteristics of Currently Unemployed

\begin{tabular}{|c|c|c|c|c|c|c|c|c|c|}
\hline \multirow[t]{2}{*}{$\begin{array}{l}\text { Search } \\
\text { method }\end{array}$} & \multicolumn{2}{|c|}{ HH employment } & \multicolumn{2}{|c|}{$\begin{array}{c}\text { Labour Market } \\
\text { contacts }\end{array}$} & \multicolumn{2}{|c|}{$\begin{array}{l}\text { HH Income } \\
\text { per Cap* }\end{array}$} & \multirow{3}{*}{$\begin{array}{c}\text { HH } \\
\begin{array}{c}\text { Adult } \\
\text { size }\end{array} \\
\mathbf{3 . 4 1} \\
(1.71) \\
\end{array}$} & \multirow{3}{*}{$\begin{array}{c}\text { HH } \\
\text { Child } \\
\text { size }\end{array}$} & \multirow{3}{*}{\begin{tabular}{|c|} 
Total \\
235 \\
\end{tabular}} \\
\hline & Yes & No & Yes & No & Med & Mean & & & \\
\hline Excl. active & $\begin{array}{c}116 \\
(25 ; 49)\end{array}$ & $\begin{array}{c}119 \\
(24 ; 51)\end{array}$ & $\begin{array}{c}\mathbf{9 5} \\
(21 ; 40)\end{array}$ & $\begin{array}{c}136 \\
(27 ; 60)\end{array}$ & 200 & 273.2 & & & \\
\hline Excl passive & $\begin{array}{c}\mathbf{7 7} \\
(16 ; 54)\end{array}$ & $\begin{array}{c}\mathbf{6 6} \\
(14 ; 46)\end{array}$ & $\begin{array}{c}\mathbf{8 6} \\
(19 ; 60)\end{array}$ & $\begin{array}{c}\mathbf{5 3} \\
(10 ; 40)\end{array}$ & 233 & 318.4 & $\begin{array}{c}\mathbf{3 . 5 2} \\
(1.66)\end{array}$ & $\begin{array}{c}\mathbf{1 . 6 7} \\
(1.57)\end{array}$ & 143 \\
\hline $\begin{array}{l}\text { Mix } \\
\text { Strategy }\end{array}$ & $\begin{array}{c}\mathbf{1 1 7} \\
(25 ; 45)\end{array}$ & $\begin{array}{c}143 \\
(28 ; 55)\end{array}$ & $\begin{array}{c}153 \\
(34 ; 59)\end{array}$ & $\begin{array}{c}\mathbf{1 0 7} \\
(20 ; 41)\end{array}$ & 200 & 270.2 & $\begin{array}{c}\mathbf{3 . 4 0} \\
(1.63)\end{array}$ & $\begin{array}{c}\mathbf{1 . 5 6} \\
(1.41)\end{array}$ & 260 \\
\hline Non search & $\begin{array}{c}157 \\
(34 ; 48)\end{array}$ & $\begin{array}{c}\mathbf{1 7 7} \\
(35 ; 52)\end{array}$ & $\begin{array}{c}117 \\
(26 ; 35)\end{array}$ & $\begin{array}{c}\mathbf{2 1 5} \\
(42 ; 65)\end{array}$ & 211 & 286.4 & $\begin{array}{c}\mathbf{3 . 1 3} \\
(1.56)\end{array}$ & $\begin{array}{c}\mathbf{1 . 8 2} \\
(1.59)\end{array}$ & 334 \\
\hline Total/Avg & $\begin{array}{c}\mathbf{4 6 7} \\
(100 ; 48) \\
\end{array}$ & $\begin{array}{c}\mathbf{5 0 5} \\
(100 ; 52)\end{array}$ & $\begin{array}{c}\mathbf{4 5 1} \\
(100 ; 46)\end{array}$ & $\begin{array}{c}\mathbf{5 1 1} \\
(100 ; 53)\end{array}$ & 200 & 283.5 & $\begin{array}{c}\mathbf{3 . 3 3} \\
(1.64)\end{array}$ & $\begin{array}{c}\mathbf{1 . 7} \\
(1.62)\end{array}$ & 972 \\
\hline
\end{tabular}

Source: KMP 2000, own calculations, Number (Column\%; Row\% or Standard Error).

Note: This is not adjusted for children or economies of scale (adult equivalence).

It was argued in the theoretical framework that the choice of the search method is a mixture of feasibility and effectiveness. The survey asked the unemployed to evaluate the effectiveness of certain search methods for the respondent's level of skill and experience. Respondents were not asked directly about the feasibility of certain search options except for some general questions on aspects which can impact the ability to search. We therefore do know which search methods the respondents perceive to be the most effective for them. In addition, we know which search methods they pursue, but we do not know why they chose these methods, or more particularly, why some searchers do not pursue methods which they perceive to be more appropriate. Respondents were not asked why they decided not to pursue certain search methods. Hence, we do not know what factors led to the decision to engage in a particular search strategy. Nevertheless, following the theoretical framework with regard to aspects which make a search option effective and feasible, we can deduce possible reasons for choosing the type of search activity.

Table 3 reports the search methods which the currently unemployed perceive as the best way of finding a job given their skill level and experience. Nonsearchers do not show any particular pattern, with $41 \%$ of them considering passive search methods to be the best way to look for a job. Mixed strategy searchers indicate that all methods are appropriate with $44 \%$ of them stating that passive search is the best way.

It is surprising that $47 \%$ of the exclusive passive searchers consider active search methods as the best way of looking for a job (non-shaded area of exclusive network search column), while $29 \%$ of the exclusive active searchers report the use of social networks as the most effective way of finding a job (non- 
shaded area of exclusive active search column). This clearly indicates that the choice of the search method is to some extent constrained, i.e. the search strategy is a compromise between what is perceived to be the best way to look for a job and what is feasible.

Table 3: Best Search Method for Skill Level (Currently Unemployed)

\begin{tabular}{|l|c|c|c|c|c|}
\hline Best Search method & Non Search & Excl Pass & Excl Act & Mix Str. & Total \\
\hline 1) Newspaper & $\mathbf{6 7}$ & $\mathbf{2 6}$ & $\mathbf{7 3}$ & $\mathbf{5 5}$ & $\mathbf{2 2 1}$ \\
& $(21,30)$ & $(19,12)$ & $(33,33)$ & $(21,25)$ & $(23,100)$ \\
\hline 2) HH Info & $\mathbf{5 3}$ & $\mathbf{2 0}$ & $\mathbf{1 9}$ & $\mathbf{2 8}$ & $\mathbf{1 2 0}$ \\
& $(16,44)$ & $(14,17)$ & $(9,16)$ & $(11,23)$ & $(13,100)$ \\
\hline 3) Other HH Info & $\mathbf{5 6}$ & $\mathbf{4 2}$ & $\mathbf{2 6}$ & $\mathbf{4 3}$ & $\mathbf{1 6 7}$ \\
& $(17,34)$ & $(30,25)$ & $(12,16)$ & $(17,26)$ & $(18,100)$ \\
\hline 4) HH Job & $\mathbf{7}$ & $\mathbf{7}$ & $\mathbf{5}$ & $\mathbf{2 1}$ & $\mathbf{4 0}$ \\
& $(2,17)$ & $(5,17)$ & $(2,13)$ & $(8,53)$ & $(4,100)$ \\
\hline 5) Other HH Job & $\mathbf{1 9}$ & $\mathbf{4}$ & $\mathbf{1 4}$ & $\mathbf{2 0}$ & $\mathbf{5 7}$ \\
& $(6,33)$ & $(3,7)$ & $(6,25)$ & $(8,35)$ & $(6,100)$ \\
\hline 6) Going factories & $\mathbf{4 4}$ & $\mathbf{1 5}$ & $\mathbf{3 5}$ & $\mathbf{3 8}$ & $\mathbf{1 3 2}$ \\
& $(14,33)$ & $(11,11)$ & $(16,27)$ & $(15,29)$ & $(14,100)$ \\
\hline 7) Knock on doors & $\mathbf{4 1}$ & $\mathbf{1 1}$ & $\mathbf{2 6}$ & $\mathbf{2 2}$ & $\mathbf{1 0 0}$ \\
& $(13,41)$ & $(8,11)$ & $(12,26)$ & $(9,22)$ & $(11,100)$ \\
\hline 8) Empl. agency & $\mathbf{1 0}$ & $\mathbf{4}$ & $\mathbf{9}$ & $\mathbf{1 1}$ & $\mathbf{3 4}$ \\
& $(3,29)$ & $(3,12)$ & $(4,26)$ & $(4,32)$ & $(4,100)$ \\
\hline 9) Prev. Employer & $\mathbf{5}$ & $\mathbf{2}$ & $\mathbf{3}$ & $\mathbf{3}$ & $\mathbf{1 3}$ \\
& $(2,38)$ & $(1,15)$ & $(1,23)$ & $(1,23)$ & $(1,100)$ \\
\hline 10) Side of road & $\mathbf{0}$ & $\mathbf{0}$ & $\mathbf{1}$ & $\mathbf{2}$ & $\mathbf{3}$ \\
& $(0,0)$ & $(0,0)$ & $(0,33)$ & $(1,66)$ & $(0,100)$ \\
\hline 11) Notice boards & $\mathbf{4}$ & $\mathbf{1}$ & $\mathbf{1}$ & $\mathbf{3}$ & $\mathbf{9}$ \\
& $(1,44)$ & $(1,11)$ & $(0,11)$ & $(1,33)$ & $(1,100)$ \\
\hline Other* & $\mathbf{1 8}$ & $\mathbf{7}$ & $\mathbf{1 1}$ & $\mathbf{1 1}$ & $\mathbf{4 7}$ \\
& $(6,38)$ & $(5,15)$ & $(5,23)$ & $(4,23)$ & $(5,100)$ \\
\hline Total & $\mathbf{3 2 4}$ & $\mathbf{1 3 9}$ & $\mathbf{2 2 3}$ & $\mathbf{2 5 7}$ & $\mathbf{9 4 3}$ \\
\hline
\end{tabular}

Source: KMP 2000, own calculations, Number (Column\%; Row\%).

Note: * 23 of the "Other" methods refer to participating in training courses, while the rest is mainly a mixture of not knowing, approaching Trade Unions, or starting their own businesses.

What constrains the searchers from pursuing more active search? Looking at table 4 we can see that the various search methods experience different levels of constraints. Exclusive passive searchers are mainly tied up in domestic duties which seem to give them no time to pursue more active search methods. Nonsearchers, also having on average the highest number of children in the household, are also constrained by domestic duties but not as much as exclusive passive searchers. Exclusive active searchers and mixed strategy searchers are the least constrained group with respect to domestic duties. 
A similar picture emerges when we look at health problems. Again, passive searchers are most hampered by health problems with $18 \%$ of them reporting that health problems have more than occasionally interfered with their ability to look for a job. Search groups which pursue more active search methods are less hindered by health problems.

Finally, although proportionally more passive searchers have indicated that hunger interfered with their ability to search for a job, all search groups seem to experience this problem to some extent.

Table 4. Constraints to Search

\begin{tabular}{|l|c|c|c|c|c|c|}
\hline $\begin{array}{l}\text { Search } \\
\text { method }\end{array}$ & $\begin{array}{c}\text { Domestic } \\
\text { Duties }\end{array}$ & \multicolumn{2}{|c|}{$\begin{array}{c}\text { Health Problems } \\
\text { Yes }\end{array}$} & \multicolumn{2}{|c|}{ Hunger } & Total \\
\hline Excl. active & $\mathbf{0 . 7 3}$ & $\mathbf{2 4}$ & $\mathbf{2 0 1}$ & $\mathbf{4 6}$ & $\mathbf{1 7 8}$ & $\mathbf{2 2 5}$ \\
& $(1.20)$ & $(22 ; 11)$ & $(24 ; 89)$ & $(24 ; 21)$ & $(23 ; 79)$ & $(24,100)$ \\
\hline Excl passive & $\mathbf{1 . 1 4}$ & $\mathbf{2 5}$ & $\mathbf{1 1 6}$ & $\mathbf{3 3}$ & $\mathbf{1 0 8}$ & $\mathbf{1 4 1}$ \\
& $(1.46)$ & $(23 ; 18)$ & $(14 ; 82)$ & $(18 ; 23)$ & $(14 ; 77)$ & $(15,100)$ \\
\hline Mix Strategy & $\mathbf{0 . 6 8}$ & $\mathbf{2 0}$ & $\mathbf{2 3 5}$ & $\mathbf{5 0}$ & $\mathbf{2 0 5}$ & $\mathbf{2 5 5}$ \\
& $(1.18)$ & $(18 ; 8)$ & $(28 ; 91)$ & $(27 ; 20)$ & $(27 ; 80)$ & $(27,100)$ \\
\hline Non search & $\mathbf{1 . 1 0}$ & $\mathbf{4 2}$ & $\mathbf{2 8 2}$ & $\mathbf{5 8}$ & $\mathbf{2 6 8}$ & $\mathbf{3 2 4}$ \\
& $(1.48)$ & $(38 ; 13)$ & $(34 ; 87)$ & $(31 ; 18)$ & $(35 ; 82)$ & $(34,100)$ \\
\hline Total/Avg & $\mathbf{0 . 9}$ & $\mathbf{1 1 1}$ & $\mathbf{8 3 4}$ & $\mathbf{1 8 7}$ & $\mathbf{7 5 9}$ & $\mathbf{9 4 5}$ \\
& $(1.35)$ & $(100 ; 12)$ & $(100 ; 88)$ & $(100 ; 20)$ & $(100 ; 80)$ & \\
\hline
\end{tabular}

Source: KMP 2000, own calculations, Number (Column\%; Row\% or Standard Error)

\section{Regression Analysis}

We have established in the descriptive analysis certain factors which can be seen as facilitators or constraints to the choice of search method. In the following regression we want to test the statistical significance of the various factors. The aim is to understand why unemployed job-seekers pursue certain search strategies.

\subsection{Methodology}

In this case using a multinominal logit model (MNLM) is the best way to test variables which determine the choice of the different search strategies Here we consider the four different search strategies: non-searchers, exclusive passive searchers, exclusive active searchers and mixed strategy searchers. Because exclusive passive searchers represent the 'grey zone' group, the first regression 
uses the exclusive passive searchers as the base group. Further regressions are attached in the appendix (See Appendix A6).

The main problem of using a MNLM is the possibility of including categories which have an impact on the comparison of two other categories. Therefore, in order to test for the independence of irrelevant alternatives (IIA) we perform a Hausman test ${ }^{5}$.

Furthermore, we have to test for the possibility of combining different outcome categories. If the independent variables do not explain the difference between two outcomes at a statistically significant level, we can assume that the two outcomes are indistinguishable and therefore should combine them. This test is particularly interesting for this paper as we want to examine factors which explain the choice of different search strategies. We can expect to see a significant overlap between exclusive network searchers and mixed strategy searchers as well as between exclusive active searchers and mixed strategy searchers. The Wald test for combining outcomes can show if the distinction we made between the different search strategies is justified ${ }^{6}$.

Finally, we test for the significance of specific variables themselves. Again utilising a Wald test for testing the effects of the independent variables, we can identify individual variables which explain the choice of the search method.

\subsection{Analysis}

The following regression establishes the factors which determine the choice of the search method. Motivated by the theoretical discussion as well as the descriptive analysis, we include individual and household variables which either constrain or facilitate the use of a search method.

As discussed above, in order to control for the independence of irrelevant alternatives, we performed the Hausman test of IIA. The results show that we cannot reject the Null hypothesis that IIA holds (See Appendix Table A3). We further examined whether some of the dependent categories could be combined into one, i.e. to what extent the categories are statistically different from one another. The Null hypothesis that all coefficients except intercepts associated with given pair of outcomes are equal (i.e., categories can be collapsed) can be rejected for almost all pairs of categories at a $1 \%$ significance level except for one pair. The only pair, for which the Null hypothesis cannot be rejected at a statistically significant level, is the combination of exclusive active searchers

\footnotetext{
${ }^{5}$ See, for a more detailed discussion, Long \& Freese (2001).

${ }^{6}$ See, for a more detailed discussion, Long \& Freese (2001).
} 
and mixed strategy searchers (see Appendix Table A4). Despite the suggestion that these two outcomes should be combined, we continue to use them separately. The reasons for this decision will be discussed later. A main limitation of the regression estimations has been the loss of a significant number of observations. Unfortunately, the high number of lost observations is the outcome of the accumulation of missing observations of various variables. Thus, it is not possible to single out one particular variable and simply exclude the variable to increase the number of observations.

The personal characteristics of the individuals do not seem to explain the differences between the search groups. Although some significance might have been lost with the low number of observations, neither race, age, marital status nor education are significant in explaining the choice of the various search strategies. Even a breakdown of different educational attainment levels has not shown any significance in any equation. Thus, the characteristics of the individuals seem to be fairly unimportant in choosing any particular search strategy. The only individual characteristic which has some significance is gender. Being female increases the probability of not searching compared to all other search strategies.

This rather surprising finding can also be seen in the Wald test for independent variables. Except for gender all other individual characteristics are not statistically significant in explaining the choice of the search strategy (See Appendix Table A5). The regression does support the main argument of this paper. The choice of the search method is determined by factors which either constrain or facilitate the pursuit of a search method. The most significant constraint on the ability of passive searchers to pursue other search methods is the obligation to do domestic duties. Domestic duties reduce the likelihood of being an exclusive active searcher or a mixed strategy searcher at a $1 \%$ significance level. Even non-searchers seem to be less restricted by domestic duties. Clearly there is a tricky causality issue here. Do domestic duties restrict the unemployed to using only social networks, or does having access to social networks allow the unemployed to spend more time fulfilling domestic chores? Given that $47 \%$ of the exclusive network searchers indicated that they see active search methods as a much more effective way of looking for a job, we argue that domestic duties force the unemployed to rely on social networks to look for a job. The significance of domestic duties is not reduced even when we control for the number of children and adults in the household. What is rather surprising is how unimportant the number of children and adults seem to be for the choice of the search method. 
Table 5: MNLR: Exclusive Passive Searchers compared to other Search Strategies

\begin{tabular}{|c|c|c|c|}
\hline \multirow[t]{2}{*}{ Multinomal logits } & \multicolumn{3}{|c|}{$\begin{array}{c}\text { Regression 1 } \\
\text { (Base Group : Excl Passive Searchers) }\end{array}$} \\
\hline & Non Search & Excl Act & Mix Str. \\
\hline Male & $\begin{array}{c}-.6658 * * \\
(.3013)\end{array}$ & $\begin{array}{c}.2786 \\
(.2971)\end{array}$ & $\begin{array}{l}.2246 \\
(.2836)\end{array}$ \\
\hline Coloured & $\begin{array}{c}.3995 \\
(.4650)\end{array}$ & $\begin{array}{r}\mathbf{4 5 3 9} \\
(4763) \\
\end{array}$ & $\begin{array}{r}-.0272 \\
(.4685)\end{array}$ \\
\hline Age & $\begin{array}{l}\mathbf{. 0 2 1 5} \dagger \\
(.0149)\end{array}$ & $\begin{array}{c}\mathbf{. 0 1 6 5} \\
(.0158)\end{array}$ & $\begin{array}{c}\mathbf{. 0 1 9 4} \\
(.0155)\end{array}$ \\
\hline Married & $\begin{array}{l}-.2819 \\
(.2921)\end{array}$ & $\begin{array}{l}-.1941 \\
(.3124)\end{array}$ & $\begin{array}{l}-.2314 \\
(.3040)\end{array}$ \\
\hline Education & $\begin{array}{c}-.0104 \\
(.0472)\end{array}$ & $\begin{array}{c}\mathbf{. 0 5 6 3} \\
(.0502) \\
\end{array}$ & $\begin{array}{l}. \mathbf{0 7 8 8} \\
(.0486) \\
\end{array}$ \\
\hline Domestic Duties & $\begin{array}{l}-.1857 * * \\
(.0909)\end{array}$ & $\begin{array}{c}-.2758 * * * \\
(.1016)\end{array}$ & $\begin{array}{c}-.2832 * * * \\
(.0969)\end{array}$ \\
\hline Health Problems & $\begin{array}{l}-.4666 \\
(.3957)\end{array}$ & $\begin{array}{l}-.3357 \\
(.4168)\end{array}$ & $\begin{array}{r}-.6760 \dagger \\
(.4192)\end{array}$ \\
\hline Hunger & $\begin{array}{c}-.7428 * * \\
(.3373)\end{array}$ & $\begin{array}{l}-.2131 \\
(.3413) \\
\end{array}$ & $\begin{array}{l}\mathbf{- . 1 7 7 4} \\
(.3210) \\
\end{array}$ \\
\hline $\begin{array}{l}\text { Unemployment } \\
\text { Length }\end{array}$ & $\begin{array}{c}. \mathbf{0 0 3 5} \\
(.0028) \\
\end{array}$ & $\begin{array}{c}\mathbf{. 0 0 1 0} \\
(.0032) \\
\end{array}$ & $\begin{array}{l}\mathbf{- . 0 0 0 8 8} \\
(.0032) \\
\end{array}$ \\
\hline Contacts & $\begin{array}{l}-.9251 * * * * \\
(.2599)\end{array}$ & $\begin{array}{c}-.7680 * * * * \\
(.2713)\end{array}$ & $\begin{array}{l}-.2206 \\
(.2606)\end{array}$ \\
\hline Local & $\begin{array}{c}\mathbf{- 1 . 1 6 0 3} * * * \\
(.4372) \\
\end{array}$ & $\begin{array}{l}-.7009 \dagger \\
(.4401) \\
\end{array}$ & $\begin{array}{l}-.7130 * \\
(.4230) \\
\end{array}$ \\
\hline HH Employment & $\begin{array}{c}-.4814 * \\
(.2898) \\
\end{array}$ & $\begin{array}{c}-.2416 \\
(.3045)\end{array}$ & $\begin{array}{c}-.4584 \dagger \\
(.2909)\end{array}$ \\
\hline $\begin{array}{l}\text { HH Income } \\
\text { per capita }\end{array}$ & $\begin{array}{c}-.0000 \\
(-.0004)\end{array}$ & $\begin{array}{l}\mathbf{- . 0 0 0 5} \\
(.0004)\end{array}$ & $\begin{array}{l}\mathbf{- . 0 0 0 3} \\
(.0004)\end{array}$ \\
\hline Child size & $\begin{array}{l}\mathbf{0 5 6 8} \\
(.0877) \\
\end{array}$ & $\begin{array}{l}\mathbf{. 0 3 6 9} \\
(.0929)\end{array}$ & $\begin{array}{l}\mathbf{. 0 1 2 9} \\
(.0905)\end{array}$ \\
\hline Adult size & $\begin{array}{l}\mathbf{. 0 6 5 3} \\
(.1086) \\
\end{array}$ & $\begin{array}{r}\mathbf{. 0 0 1 3} \\
(.1124) \\
\end{array}$ & $\begin{array}{r}\mathbf{. 0 0 1 7} \\
(.1082) \\
\end{array}$ \\
\hline $\begin{array}{l}\text { HH Active } \\
\text { Search }\end{array}$ & $\begin{array}{l}\mathbf{. 6 9 2 7} \dagger \\
(.4385) \\
\end{array}$ & $\begin{array}{c}. \mathbf{4 7 7 3} \\
(.4540) \\
\end{array}$ & $\begin{array}{l}\mathbf{6 7 3 1 \dagger} \\
(.4338) \\
\end{array}$ \\
\hline $\begin{array}{l}\text { HH Network } \\
\text { Search }\end{array}$ & $\begin{array}{c}\mathbf{- 1 . 2 0 4 3} * * * \\
(.4295)\end{array}$ & $\begin{array}{c}\mathbf{- 1 . 3 2 9 2 * * *} \\
(.4595)\end{array}$ & $\begin{array}{l}-.6204 \dagger \\
(.3910)\end{array}$ \\
\hline $\begin{array}{l}\text { HH Mixed } \\
\text { Strategy Search }\end{array}$ & $\begin{array}{c}-\mathbf{8 5 8 7} * * \\
(.4001)\end{array}$ & $\begin{array}{l}\mathbf{- . 0 1 7 1} \\
(.3861)\end{array}$ & $\begin{array}{l}\mathbf{. 1 4 3 3} \\
(.3632)\end{array}$ \\
\hline Constant & $\begin{array}{l}\text { 1.4458* } \\
(.7941)\end{array}$ & $\begin{array}{l}. \mathbf{4 4 1 4} \\
(.8426)\end{array}$ & $\begin{array}{l}\mathbf{. 3 1 5 3} \\
(.8209)\end{array}$ \\
\hline Observations & & 649 & \\
\hline LR Chi2 (36) & & 135.39 & \\
\hline Prob>chi2 & & 0.0000 & \\
\hline Pseudo R2 & & 0.0770 & \\
\hline
\end{tabular}

Notes: Significance levels: $\dagger$ between $10 \%$ and $15 \% ; *$ at the $10 \%$ level; $* *$ at the $5 \%$ level and $* * *$ at the $1 \%$ level 
Other possible constraints to the pursuit of certain search options like health problems and hunger are fairly insignificant factors. What is interesting is the fact that hunger seems to have affected all searching unemployed except for the non-searchers (see Appendix Regression A6). This could be explained in two ways. Either the non-searchers have not experienced hunger as a search constraint because they do not search in the first place, or the non-searchers are in general better off than searching unemployed, which would indicate that finding a job is less urgent for the non-searchers compared to the rest.

In terms of facilitating certain search methods, the regression shows that the availability of contacts significantly explains the difference between utilising social networks and other search methods. Contacts with other workers in the labour market increase the likelihood of being an exclusive passive searcher rather than a non searcher or an exclusive active searcher at a $1 \%$ significance level. As expected, contacts do not explain the difference between exclusive passive searchers and mixed strategy searchers as both groups use these contacts to increase their probability of finding a job. Interestingly, contacts are the main difference between exclusive active searchers and mixed strategy searchers (see Appendix Regression A7). The Wald test for combining outcomes suggests that the two groups are not statistically different except for these contacts. This finding is exactly the point of this paper. The difference between choosing to use social networks and pursuing active search is determined by the availability of social contacts. When such contacts are available people will use them. The use of social networks is furthermore strongly determined by the embeddedness of the job searcher. Being a migrant reduces the likelihood of being an exclusive passive searcher. Thus, exclusive passive searchers seem to be embedded into a locally defined social network. Migrants on the other hand have to build these networks first. Especially for non-searchers the distinction between being locally born and having migrated to Cape Town is highly significant. As was already established, non-searchers have the lowest number of contacts to the labour market as well as the lowest number of household employment. Following Dinkelman and Pirouz (2001), non-searchers therefore have the weakest degree of attachment to the labour market. Being a local also reduces the likelihood of being an exclusive active searcher or a mixed strategy searcher although both are only weakly significant.

More household employment decreases the likelihood of using a search method other than passive search. This though is only weakly significant for non searchers and mixed strategy searchers and not significant for exclusive active searchers. These combinations make the interpretation of the results slightly more difficult. Considering that exclusive active and exclusive network searchers have other employed members in their household, household employment seems to affect the search strategy in two different ways. On the 
one hand, it can increase the information flow or on the other hand give access to financial resources which again can either finance active search or reduce the intensity of the search activities. The last point is not supported by the regression as there is no statistical difference among the search groups with respect to household income per capita. Nevertheless, household employment does influence the search behaviour of the unemployed. It seems that household employment gives access to finance in order to pursue active search but when people are time constrained because of domestic duties, then households function mainly as an information transmitters.

Finally, households seem to create some kind of search culture. More exclusive passive searchers find themselves in households where other household members also rely exclusively on social networks. In terms of active search, exclusive passive searchers have fewer household members who pursue exclusive active search methods compared with other search groups. Thus, it does not seem that there is a division of labour in terms of the search activity where some household members search actively and the rest rely on the information which comes back to the household. Rather the structure of the household creates conditions which are conducive for the adoption of a particular search strategy. Again, one could speculate that the search strategy of the household seems to be closely related to the availability of contacts in the labour market.

\section{Conclusion}

The key findings from our empirical work can be summarised as follows. First, the choice of search strategy is more an outcome of constraints and facilitators than individual characteristics. Domestic duties in particular restrict the exclusive passive searcher from spending time on active search methods while more active searchers are not tied up in such domestic chores. At the same time being embedded in a locally defined social network and having a high level of household employment and local contacts enable the exclusive passive searcher to rely on friends and family to get access to the labour market. The less the unemployed are embedded in local networks, the higher is the probability of these unemployed engaging in active search methods. Exclusive active searchers are the least embedded group and this might explain their exclusive use of active search methods. Mixed strategy searchers are least constrained and fairly well embedded which make the pursuit of the entire range of search methods available and feasible.

This empirical work suggests that much is lost by treating search simply as the sum of all search activities and by dividing labour force participants along the 
simple dichotomy of searching versus non-searching. As our study has shown, the choice of the search method is complicated and is always a constrained decision with individuals often having to choose search options that they know to be inferior to other option that are unaffordable in terms of time or money. Indeed, it is the constraining and facilitating characteristics of the household and the social environment of the unemployed that seem to be binding factors in their search outcomes. When these factors change one could expect that the search behaviour of the unemployed adjusts as well to the new situation.

Given our results, the way in which the strict unemployment rate is calculated by Stats SA does not adequately capture the search behaviour of South Africa's unemployed and, therefore, is inadequate in indicating the participation of jobseekers in the South African labour market. However, this is not a simple argument in support of the use of the broad unemployment rate rather than the strict unemployment rate. Indeed one of the purposes of this paper has been to show that even those unemployed who are regarded by the strict definition of unemployment as non-searching, discouraged workers are involved in a variety of search activities. Thus, when they are seen through the lens of search behaviour, it is not clear that these discouraged workers are all equally discouraged or they make up an analytically coherent group. Clearly, the mapping of search behaviour onto existing statistical definitions of unemployment is complicated. We have endeavoured to make a strong case for the importance of understanding search behaviour to support a call for the national Labour Force Survey to devote more attention to generating sufficient information to analyse the search methods pursued by the job-seekers. 


\section{Reference}

Development Policy Research Unit (DPRU) (2004), Socioeconomic Change in Post-Apartheid South Africa: The Labour Market 1995-2002, Cape Town: Development Policy Research Unit, University of Cape Town.

Dinkelman T. L. (2004), How Household Context affects Search Outcomes of the Unemployed in Kwazulu-Natal, South Africa: A Panel Data Analysis, South African Journal of Economics, Vol. 72, No. 3

Dinkelman T. \& Pirouz F. (2001), Individual, Household and Regional Determinants of Labour Force Attachment in South Africa: Evidence from the 1997 October Household Survey, TIPS Working Paper 1-2001. Johannesburg: Trade \& Industrial Policy Secretariat (TIPS)

Duff P. \& Fryer D. (2004), "The Dynamics of Job Search and the Microfoundations of Unemployment: Evidence from Duncan Village", paper presented at the DPRU conference "African Development and Poverty Reduction: the Micro-Macro Linkage", Cape Town: Development Policy Research Unit, University of Cape Town.

Khayelitsha/Mitchell's Plain Survey, (2000), South African Labour and Development Research Unit (SALDRU), University of Cape Town (UCT)

Kingdon G. \& Knight J. (2000), “Are Searching and Non-Searching Unemployment Distinct States when Unemployment is High? The Case of South Africa", WPS/2000-2, Centre for the Study of African Economics: University of Oxford

Kingdon G. \& Knight J. (2001), "What have we learnt about unemployment from microdatasets in South Africa?", mimeo, Centre for the Study of African Economics: University of Oxford

Long J.S. \& Freese J. (2001), Regression Models for Categorical Dependent Variables Using Stata, Texas: Stata Press Publication

McEntarfer E. (2002), "Three Essays on Social Networks in Labor Markets", $\mathrm{PhD}$ paper, Virginia Polytechnic Institute and State University

Nattrass N. (2002), Unemployment, Employment and Labour Force Participation in Khayelitsha/Mitchell's Plain, CSSR Working Paper No. 
12. Cape Town: Centre for Social Science Research, University of Cape Town

Nattrass N. \& Walker R. (2005), Unemployment and Reservation Wages in Working-Class Cape Town", South African Journal of Economics, Vol. 77, No. 3: 498-509

Osberg L (1993), "Fishing in Different Pools: Job-Search Strategies and JobFinding Success in Canada in the Early 1980s", Journal of Labor Economics, Vol11, No.2: 348-386

Pissarides C.A. (2000), Equilibrium Unemployment Theory, London: MIT Press

Seekings J. (2003), Do South Africa's Unemployed Constitute an Underclass?, CSSR Working Paper 32, Cape Town: Centre for Social Science Research, University of Cape Town

Statistics SA (1998), Unemployment and Employment in South Africa, Pretoria: StatsSA

Statistics SA (2002), Labour Force Survey: Statistical Release P0210, Pretoria: StatsSA

Stigler G.J. (1962), "Information in the Labour Market", The Journal of Political Economy, Vol. 70, No. 5, Part 2: 94-105

Wittenberg M. (1999), Job Search and Household Structure in an Era of Mass Unemployment: A Semi-parametric Analysis of the South African Labour Market, Working Paper 22, Potchefstroom: South African Network for Economic Research (SANER)

Wittenberg M. (2001), "Spatial Dimensions of Unemployment", conference paper at DPRU/FES conference 'Labour Markets and Poverty in South Africa”, Johannesburg 


\section{Appendix}

Table A1: Search Strategies of Currently Unemployed in KMP Survey

\begin{tabular}{|l|c|c|}
\hline Search Strategy & Number & Percentage \\
\hline Exclusive Active & 235 & $24 \%$ \\
\hline Exclusive Passive & 143 & $15 \%$ \\
\hline Mixed Strategy & 260 & $27 \%$ \\
\hline Non Searching & 334 & $34 \%$ \\
\hline Total & 972 & $100 \%$ \\
\hline
\end{tabular}

Source: KMP 2000, own calculations.

Table A2: Length of Current Unemployment in Months

\begin{tabular}{|l|c|c|c|c|c|c|c|}
\hline $\begin{array}{l}\text { Search } \\
\text { method }\end{array}$ & $\begin{array}{c}\mathbf{0 - 6} \\
\text { months }\end{array}$ & $\begin{array}{c}\mathbf{7 - 1 2} \\
\text { months }\end{array}$ & $\begin{array}{c}\mathbf{1 - 2} \\
\text { Years }\end{array}$ & $\begin{array}{c}\mathbf{2 - 4} \\
\text { Years }\end{array}$ & $\begin{array}{c}\mathbf{4 - 8} \\
\text { Years }\end{array}$ & $\begin{array}{c}\mathbf{8 +} \\
\text { Years }\end{array}$ & Total \\
\hline Excl. active & $\mathbf{4 5}$ & $\mathbf{4 5}$ & $\mathbf{4 2}$ & $\mathbf{4 5}$ & $\mathbf{2 7}$ & $\mathbf{2 6}$ & $\mathbf{2 3 0}$ \\
& $(28 ; 20)$ & $(26 ; 20)$ & $(23 ; 18)$ & $(25 ; 20)$ & $(19 ; 11)$ & $(25 ; 11)$ & \\
\hline Excl & $\mathbf{2 0}$ & $\mathbf{3 0}$ & $\mathbf{3 0}$ & $\mathbf{2 8}$ & $\mathbf{1 9}$ & $\mathbf{1 3}$ & $\mathbf{1 4 0}$ \\
passive & $(12 ; 15)$ & $(17 ; 21)$ & $(17 ; 21)$ & $(16 ; 20)$ & $(15 ; 14)$ & $(12 ; 9)$ & \\
\hline Mix & $\mathbf{4 8}$ & $\mathbf{4 8}$ & $\mathbf{5 2}$ & $\mathbf{4 4}$ & $\mathbf{3 9}$ & $\mathbf{1 6}$ & $\mathbf{2 4 7}$ \\
Strategy & $(30 ; 19)$ & $(27 ; 19)$ & $(29 ; 21)$ & $(25 ; 18)$ & $(31 ; 16)$ & $(15 ; 6)$ & \\
\hline Non search & $\mathbf{4 8}$ & $\mathbf{5 3}$ & $\mathbf{5 7}$ & $\mathbf{6 2}$ & $\mathbf{3 9}$ & $\mathbf{5 0}$ & $\mathbf{3 0 9}$ \\
& $(30 ; 16)$ & $(30 ; 17)$ & $(31 ; 18)$ & $(35 ; 20)$ & $(31 ; 13)$ & $(48 ; 16)$ & \\
\hline Total & $\mathbf{1 6 1}$ & $\mathbf{1 7 6}$ & $\mathbf{1 8 1}$ & $\mathbf{1 7 9}$ & $\mathbf{1 2 4}$ & $\mathbf{1 0 5}$ & $\mathbf{9 2 6}$ \\
& $(100 ; 17)$ & $(100 ; 19)$ & $(100 ; 20)$ & $(100 ; 19)$ & $(100 ;$ & $(100 ;$ & \\
& & & & & $13)$ & $11)$ & \\
\hline
\end{tabular}

Source: KMP 2000, own calculations, Number (Column\%, Row\%).

Table A3: Hausman Test for IIA

\begin{tabular}{|l|l|l|l|l|l|}
\hline Omitted & chi2 & df & P>chi2 & evidence & \\
\hline & & & & & \\
\hline 0 & -2.804 & 36 & 1.000 & for Ho & \\
\hline 2 & 4.501 & 36 & 1.000 & for Ho & \\
\hline 3 & -2.347 & 37 & 1.000 & for Ho & \\
\hline 1 & 2.663 & 36 & 1.000 & for Ho & \\
\hline
\end{tabular}

Source: KMP 2000, own calculations. 
Table A4: Wald Test of Possibility of Combing Outcomes

\begin{tabular}{|l|l|l|l|l|}
\hline Categories & tested & chi2 & df & P>chi2 \\
\hline & & & & \\
\hline $0-$ & 2 & 36.584 & 18 & 0.006 \\
\hline $0-$ & 3 & 61.267 & 18 & 0.000 \\
\hline $0-$ & 1 & 54.343 & 18 & 0.000 \\
\hline $2-$ & 3 & 16.473 & 18 & 0.560 \\
\hline $2-$ & 1 & 32.801 & 18 & 0.018 \\
\hline $3-$ & 1 & 32.285 & 18 & 0.02 \\
\hline
\end{tabular}

Source: KMP 2000, own calculations.

Table A5: Wald Test for Independent Variables

\begin{tabular}{|llll|}
\hline wantjob_unemp & chi2 & df & P>chi2 \\
\hline Gender & & & \\
\hline Race & 16.950 & 3 & 0.001 \\
\hline Age & 2.043 & 3 & 0.564 \\
\hline Marit & 2.202 & 3 & 0.532 \\
\hline Education & 0.967 & 3 & 0.809 \\
\hline Dom_Duties & 6.115 & 3 & 0.106 \\
\hline Health & 10.496 & 3 & 0.015 \\
\hline Hunger & 2.769 & 3 & 0.429 \\
\hline Len. Unemp & 6.050 & 3 & 0.109 \\
\hline Contact & 3.743 & 3 & 0.291 \\
\hline Local & 18.932 & 3 & 0.000 \\
\hline HH Emp & 7.068 & 3 & 0.070 \\
\hline HHinc_percap & 3.576 & 3 & 0.311 \\
\hline Childsize & 1.495 & 3 & 0.683 \\
\hline Adultsize & 0.561 & 3 & 0.905 \\
\hline HH active Search & 0.664 & 3 & 0.882 \\
\hline HH Network Search & 2.817 & 3 & 0.421 \\
\hline HH Mix Search & 9.877 & 3 & 0.010 \\
\hline SOuce: KMP 2000,0wn & 3 & 0.020 \\
\hline
\end{tabular}

Source: KMP 2000, own calculations. 
Table A6: MNLM Regressions of Constraints and Facilitators of Search Strategies

\begin{tabular}{|c|c|c|c|c|c|c|}
\hline \multirow[t]{2}{*}{$\begin{array}{l}\text { Multinomal } \\
\text { logits }\end{array}$} & \multicolumn{3}{|c|}{$\begin{array}{c}\text { Regression 2 } \\
\text { (Base Group : Non-Searchers) } \\
\end{array}$} & \multicolumn{3}{|c|}{$\begin{array}{c}\text { Regression 3 } \\
\text { (Base Group : Excl Act Searchers) } \\
\end{array}$} \\
\hline & \begin{tabular}{|l|} 
Excl \\
Network \\
\end{tabular} & \begin{tabular}{|l|} 
Excl \\
Active \\
\end{tabular} & \begin{tabular}{|l|} 
Mix \\
Strategy \\
\end{tabular} & \begin{tabular}{|l|} 
Non \\
Search
\end{tabular} & \begin{tabular}{|l|} 
Excl \\
Network
\end{tabular} & \begin{tabular}{|l|} 
Mix \\
Strategy \\
\end{tabular} \\
\hline Male & \begin{tabular}{|l|}
$\mathbf{. 6 6 5 8}^{* * *}$ \\
$(.3013)$ \\
\end{tabular} & \begin{tabular}{|l|}
$.9444 * * * *$ \\
$(.2588)$
\end{tabular} & \begin{tabular}{|l|l}
$\mathbf{8 9 0 5} * * * *$ \\
$(.2499)$ \\
\end{tabular} & $\begin{array}{l}-.9444 * * * \\
(.2588)\end{array}$ & \begin{tabular}{|l|}
-.2786 \\
$(.2971)$ \\
\end{tabular} & \begin{tabular}{|l|}
-.0539 \\
$(.2453)$ \\
\end{tabular} \\
\hline Coloured & $\begin{array}{ll}-.3995 \\
(.4650) \\
\end{array}$ & \begin{tabular}{|l|}
$\mathbf{. 0 5 4 3}$ \\
$(3993)$ \\
\end{tabular} & $\begin{array}{ll}-.4267 \\
(.4053) \\
\end{array}$ & \begin{tabular}{|l|}
-.0543 \\
$(3993)$ \\
\end{tabular} & \begin{tabular}{|l|l|}
.4539 \\
$(4763)$
\end{tabular} & \begin{tabular}{|l|}
. .4811 \\
$(.4147)$ \\
\end{tabular} \\
\hline Age & $\begin{array}{l}-.0215 \dagger \\
(.0149)\end{array}$ & $\begin{array}{l}-.0050 \\
(.0121)\end{array}$ & $\begin{array}{l}-.0021 \\
(.0120)\end{array}$ & $\begin{array}{l}\mathbf{. 0 0 5 0} \\
(.0121)\end{array}$ & $\begin{array}{l}-.0165 \\
(.0158)\end{array}$ & $\begin{array}{l}-.0029 \\
(.0128)\end{array}$ \\
\hline Married & $\begin{array}{l}.2819 \\
(.2921)\end{array}$ & $\begin{array}{l}.0877 \\
(.2548)\end{array}$ & $\begin{array}{l}.0504 \\
(.2501)\end{array}$ & $\begin{array}{l}-.0877 \\
(.2548)\end{array}$ & $\begin{array}{l}.1941 \\
(.3124)\end{array}$ & $\begin{array}{l}.0372 \\
(.2703)\end{array}$ \\
\hline Education & \begin{tabular}{|l|}
$\mathbf{. 0 1 0 4}$ \\
$(.0472)$
\end{tabular} & $\begin{array}{l}.0668 \\
(.0417)\end{array}$ & \begin{tabular}{|l}
$\mathbf{. 0 8 9 2} * *$ \\
$(.0406)$
\end{tabular} & $\begin{array}{l}-.0668 \\
(.0417)\end{array}$ & $\begin{array}{l}\mathbf{- . 0 5 6 3} \\
(.0502)\end{array}$ & $\begin{array}{l}.0224 \\
(.0434)\end{array}$ \\
\hline Domestic Duties & $\begin{array}{l}\mathbf{1 8 5 7} * * \\
(.0909)\end{array}$ & $\begin{array}{l}-.0901 \\
(.0891)\end{array}$ & $\begin{array}{l}-.0975 \\
(.0862)\end{array}$ & $\begin{array}{l}.0901 \\
(.0891)\end{array}$ & $\begin{array}{l}. \mathbf{2 7 5 8} * * * \\
(.1016)\end{array}$ & $\begin{array}{l}.0073 \\
(.0971)\end{array}$ \\
\hline $\begin{array}{l}\text { Health } \\
\text { Problems }\end{array}$ & \begin{tabular}{|l|}
$\mathbf{. 4 6 6 6}$ \\
$(.3957)$ \\
\end{tabular} & $\begin{array}{l}. \mathbf{1 3 0 8} \\
(.3659)\end{array}$ & $\begin{array}{l}-.2094 \\
(.3814)\end{array}$ & $\begin{array}{l}-.1308 \\
(.3659)\end{array}$ & $\begin{array}{l}.3357 \\
(.4168)\end{array}$ & \begin{tabular}{|l|}
-.3402 \\
$(.3989)$
\end{tabular} \\
\hline Hunger & \begin{tabular}{|l|}
$\mathbf{. 7 4 2 8} * * *$ \\
$(.3373)$
\end{tabular} & $\begin{array}{l}.5296 * \\
(.3069)\end{array}$ & $\begin{array}{l}.5653 * \\
(.2926)\end{array}$ & \begin{tabular}{|l}
$\mathbf{- . 5 2 9 6 *}$ \\
$(.3069)$ \\
\end{tabular} & $\begin{array}{l}.2131 \\
(.3413)\end{array}$ & $\begin{array}{l}-. .0357 \\
(.2909) \\
\end{array}$ \\
\hline $\begin{array}{l}\text { Unemployment } \\
\text { Length }\end{array}$ & \begin{tabular}{|l|}
$\mathbf{- . 0 0 3 5}$ \\
$(.0028)$ \\
\end{tabular} & $\begin{array}{l}-.0025 \\
(.0024) \\
\end{array}$ & $\begin{array}{l}. .0044 \\
(.0025) \\
\end{array}$ & \begin{tabular}{|l|}
$\mathbf{. 0 0 2 5}$ \\
$(.0024)$ \\
\end{tabular} & $\begin{array}{l}\mathbf{- . 0 0 1 0} \\
(.0032) \\
\end{array}$ & \begin{tabular}{|l|}
-.0019 \\
$(.0028)$ \\
\end{tabular} \\
\hline Contacts & \begin{tabular}{|l|}
$\mathbf{9 2 5 1} * * * *$ \\
$(.2599)$ \\
\end{tabular} & $\begin{array}{l}\mathbf{1 5 7 1} \\
(.2292) \\
\end{array}$ & \begin{tabular}{|l|}
$\mathbf{. 7 0 4 4} * * * *$ \\
$(.2185)$ \\
\end{tabular} & $\begin{array}{l}-. .1571 \\
(.2292) \\
\end{array}$ & $\begin{array}{l}\mathbf{. 7 6 8 0} * * * \\
(.2713) \\
\end{array}$ & \begin{tabular}{|l|}
$\mathbf{5 4 7 3} * *$ \\
$(.2281)$ \\
\end{tabular} \\
\hline Local & $\begin{array}{l}\mathbf{1 . 1 6 0 3} * * * * \\
(.4372)\end{array}$ & $\begin{array}{l}\mathbf{4 5 9 3} \\
(.3935) \\
\end{array}$ & $\begin{array}{l}\mathbf{4 4 7 3} \\
(.3902) \\
\end{array}$ & \begin{tabular}{|l|}
-.4593 \\
$(.3935)$
\end{tabular} & $\begin{array}{l}\mathbf{7 0 0 9} \dagger \\
(.4401)\end{array}$ & \begin{tabular}{|l|}
-.0120 \\
$(.3899)$ \\
\end{tabular} \\
\hline HH employment & \begin{tabular}{|l|}
$\mathbf{4 8 1 4} *$ \\
$(.2898)$ \\
\end{tabular} & \begin{tabular}{|l|}
.2398 \\
$(.2571)$ \\
\end{tabular} & $\begin{array}{l}\mathbf{. 0 2 3 0} \\
(.2473)\end{array}$ & \begin{tabular}{|l|}
-.2398 \\
$(.2571)$ \\
\end{tabular} & $\begin{array}{l}. \mathbf{2 4 1 6} \\
(.3045)\end{array}$ & \begin{tabular}{|l|}
-.2168 \\
$(.2602)$ \\
\end{tabular} \\
\hline $\begin{array}{l}\text { HH income per } \\
\text { cap }\end{array}$ & \begin{tabular}{|l|}
$\mathbf{. 0 0 0 0}$ \\
$(-.0004)$ \\
\end{tabular} & $\begin{array}{l}-.0004 \\
(.0004) \\
\end{array}$ & $\begin{array}{l}. .0002 \\
(.0004)\end{array}$ & $\begin{array}{l}\mathbf{. 0 0 0 4} \\
(.0004)\end{array}$ & $\begin{array}{l}. \mathbf{0 0 0 5} \\
(.0004)\end{array}$ & $\begin{array}{l}.0001 \\
(.0004)\end{array}$ \\
\hline Child size & \begin{tabular}{|l|}
$\mathbf{- . 0 5 6 8}$ \\
$(.0877)$ \\
\end{tabular} & $\begin{array}{l}-.0199 \\
(.0763) \\
\end{array}$ & $\begin{array}{l}. .0438 \\
(.0751) \\
\end{array}$ & $\begin{array}{l}.0199 \\
(.0763) \\
\end{array}$ & $\begin{array}{l}. \mathbf{0 3 6 9} \\
(.0929) \\
\end{array}$ & $\begin{array}{l}. .0239 \\
(.0793) \\
\end{array}$ \\
\hline Adult size & $\begin{array}{l}-.0653 \\
(.1086)\end{array}$ & $\begin{array}{l}. \mathbf{0 6 4 0} \\
(.0970)\end{array}$ & $\begin{array}{l}.0636 \\
(.0941)\end{array}$ & \begin{tabular}{|l|}
. .0640 \\
$(.0970)$
\end{tabular} & $\begin{array}{l}. .0013 \\
(.1124)\end{array}$ & $\begin{array}{l}.0003 \\
(.0966)\end{array}$ \\
\hline $\begin{array}{l}\text { HH Active } \\
\text { Search }\end{array}$ & \begin{tabular}{|l|}
$-.6927 \dagger$ \\
$(.4385)$
\end{tabular} & $\begin{array}{l}. \mathbf{2 1 5 3} \\
(.3320) \\
\end{array}$ & $\begin{array}{l}\mathbf{- 0 5 5 5} . \\
(.3165)\end{array}$ & $\begin{array}{l}. \mathbf{2 1 5 3} \\
(.3320)\end{array}$ & $\begin{array}{l}.4773 \\
(.4540)\end{array}$ & $\begin{array}{l}\mathbf{1 5 9 8} \\
(.3316) \\
\end{array}$ \\
\hline $\begin{array}{l}\text { HH Network } \\
\text { Search }\end{array}$ & \begin{tabular}{|l|}
1.2043 \\
$(.4295)$
\end{tabular} & \begin{tabular}{|l|}
$\mathbf{- . 1 2 4 9}$ \\
$(.4642)$ \\
\end{tabular} & $\begin{array}{l}\mathbf{5 8 3 9} \dagger \\
(.4002) \\
\end{array}$ & \begin{tabular}{|l|}
$\mathbf{1 2 4 9}$ \\
$(.4642)$ \\
\end{tabular} & $\begin{array}{l}\mathbf{1 . 3 2 9 2} * * * * \\
(.4595)\end{array}$ & \begin{tabular}{|l|}
$.7088 *$ \\
$(.4271)$ \\
\end{tabular} \\
\hline $\begin{array}{l}\text { HH Mixed } \\
\text { Strategy Search }\end{array}$ & $\begin{array}{l}\mathbf{8 5 8 7} * * * \\
(.4001) \\
\end{array}$ & \begin{tabular}{|l|}
$\mathbf{8 4 1 6} * * *$ \\
$(.3530)$ \\
\end{tabular} & $\begin{array}{l}1.0021 * * * * \\
(.3332)\end{array}$ & $\begin{array}{l}\mathbf{- . 8 4 1 6} \text { *** } \\
(.3530) \\
\end{array}$ & $\begin{array}{l}\mathbf{. 0 1 7 1} \\
(.3861)\end{array}$ & $\begin{array}{l}\mathbf{1 6 0 4} \\
(.3125) \\
\end{array}$ \\
\hline Constant & \begin{tabular}{|l|}
$\mathbf{- 1 . 4 4 5 8} *$ \\
$(.7941)$ \\
\end{tabular} & \begin{tabular}{|l|}
$\mathbf{- 1 . 0 0 4 3}$ \\
$(.6791)$ \\
\end{tabular} & \begin{tabular}{|l|}
$\mathbf{- 1 . 1 3 0 4}$ \\
$(.6668)$ \\
\end{tabular} & $\begin{array}{l}\mathbf{1 . 0 0 4 3} \\
.6791) \\
\end{array}$ & $\begin{array}{l}. .4414 \\
(.8426) \\
\end{array}$ & \begin{tabular}{|l|}
-.1261 \\
$(.7145)$
\end{tabular} \\
\hline Observations & \multicolumn{3}{|c|}{649} & \multicolumn{3}{|c|}{649} \\
\hline LR Chi2 (36) & \multicolumn{3}{|c|}{135.39} & \multicolumn{3}{|c|}{135.39} \\
\hline Prob>chi2 & \multicolumn{3}{|c|}{ 0.0000 } & \multicolumn{3}{|c|}{0.0000} \\
\hline Pseudo R2 & \multicolumn{3}{|c|}{0.0770} & \multicolumn{3}{|c|}{0.0770} \\
\hline
\end{tabular}

Notes: Significance levels: $\dagger$ between $10 \%$ and $15 \%$; $*$ at the $10 \%$ level; $* *$ at the $5 \%$ level and $* * *$ at the $1 \%$ level. 